\title{
Compliance with Quality Standards and Causes of Incomplete Colonoscopy: A Prospective Observational Study
}

\section{Kolonoskopide Kalite Standartlarına Uyum ve İnkomplet Kolonoskopi Nedenleri: Prospektif Gözlemsel Çalışma}

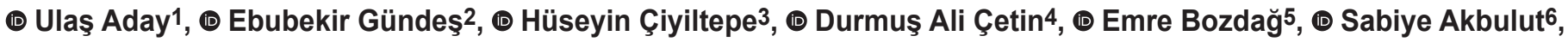 \\ (1) Rabia Köksal6, (1) Erdal Polat5 \\ 1 University of Health Sciences, Elazığ Training and Research Hospital, Clinic of Gastroenterological Surgery, Elazığ, Turkey \\ 2University of Health Sciences, Gaziyaşargil Training and Research Hospital, Clinic of Gastroenterological Surgery, Diyarbakır, Turkey \\ 3University of Health Sciences, Balıkesir Training and Research Hospital, Clinic of Gastroenterological Surgery, Balıkesir, Turkey \\ ${ }^{4}$ Şanlıurfa Training and Research Hospital, Clinic of Gastroenterological Surgery, Şanlıurfa, Turkey \\ 5University of Health Sciences, Kartal Koşuyolu Yüksek İhtisas Training and Research Hospital, Clinic of Gastroenterologcal Surgery, İstanbul, \\ Turkey \\ 6University of Health Sciences, Kartal Koşuyolu Yüksek İhtisas Training and Research Hospital, Clinic of Gastroenterology, İstanbul, Turkey
}

\section{|IIIIIII|| ABSTRACT}

Aim: To evaluate incomplete colonoscopy rate, factors affecting incomplete colonoscopy, and compliance with colonoscopy quality standards in our clinic.

Method: This prospective study was conducted in a tertiary health center between January 2017 and December 2017. Demographic characteristics of individuals undergoing colonoscopy, their colon cleansing status, causes of incomplete colonoscopy, and factors affecting incomplete colonoscopy were investigated.

Results: A total of 756 people were included in this study. The mean age was $54 \pm 12.74$ years and $63 \%$ of the patients were female. Mean body mass index (BMI) was $28.32 \pm 4.84$ and $309(40.9 \%)$ had history of prior abdominal surgery. The duration of cecal intubation was $355 \pm 187$ seconds and colonoscopy could not be completed in 89 patients (11.8\%). Advanced age ( $\mathrm{p}=0.036)$, female gender ( $\mathrm{p}=0.036)$, high BMI values ( $\mathrm{p}=0.042)$, presence of comorbidity ( $\mathrm{p}=0.004)$, antiaggregant/anticoagulant use $(\mathrm{p}=0.001)$, and inadequate bowel cleansing $(\mathrm{p}<0.001)$ were found to be significant factors for incomplete colonoscopy. Excluding the patients who had inadequate colon cleansing and were recommended to repeat the procedure, colonoscopy was completed in $93.9 \%(667 / 710)$ of patients. Inadequate bowel preparation was the most common cause of incomplete colonoscopy (51.6\%) and male gender ( $\mathrm{p}=0.047)$, antiaggregant/anticoagulant use ( $\mathrm{p}=0.021)$ were identified as factors affecting colon cleansing. Polyp detection rate was $24.7 \%$ (165/667), below the currently recommended rate of detection of adenoma.

Conclusion: Inadequate bowel preparation, advanced age, female gender, high BMI, presence of comorbidity, use of antiaggregant/anticoagulant are risk factors for incomplete colonoscopy. We are below colonoscopy quality standards due to high incomplete colonoscopy rate and low adenoma detection rate due to inadequate bowel preparation.

Keywords: Incomplete colonoscopy, bowel preparation, quality in colonoscopy

\section{|IIIIIII|| ÖZ}

Amaç: Kolorektal patolojilerin tanısında kolonoskopi altın standarttır ve klinik uygulamalarda sık yapılan bir işlemdir. Bu çalışmada inkomplet kolonoskopi oranı, kolonoskopinin tamamlanmamasına etki eden faktörler ve kliniğimizin kolonoskopi kalite standartlarına uygunluğunun değerlendirilmesi amaçlanmıştır.

Address for Correspondence/Yazışma Adresi: Ulaş Aday MD,

University of Health Sciences, Elazı̆̆ Training and Research Hospital, Clinic of Gastroenterological Surgery, Elazığ, Turkey

Phone: +90 5302933895 E-mail: ulasaday@gmail.com ORCID ID: orcid.org/0000-0002-3161-0923

Received/Geliş Tarihi: 13.08.2018 Accepted/Kabul Tarihi: 12.09.2018

${ }^{\circ}$ Copyright 2019 by Turkish Society of Colon and Rectal Surgery

Turkish Journal of Colorectal Disease published by Galenos Publishing House. 
Yöntem: Çalışma Ocak 2017-Aralık 2017 tarihleri arasında üçüncü basamak sağlık merkezinde prospektif olarak yapıldı. Kolonoskopi yapılan bireylerin demografik özellikleri, kolon temizlik durumu, inkomplet kolonoskopi nedenleri ve inkomplet kolonoskopiye etki eden faktörler incelendi. Kolonoskopisi tamamlanan ve tamamlanmayan popülasyon karşılaştırıldı.

Bulgular: Toplam 756 kişi çalışmaya alındı. Yaş ortalaması 54 12,74 yıl olup \%63’ü kadındı. Üç yüz kırk yedisinde (\%45,9) komorbidite mevcuttu. Popülasyonun vücut kitle endeksi (VKİ) ortalaması 28,32 4 ,84 olup, 309'unda (\%40,9) geçirilmiş batın cerrahi öyküsü vardı. Çekum entübasyon

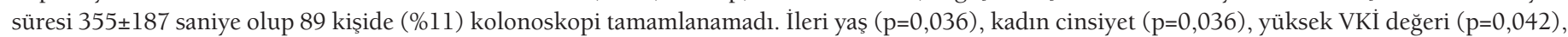
komorbidite varlığı $(\mathrm{p}=0,004)$, antiagregan/antikoagülan kullanımı $(\mathrm{p}=0,001)$, yetersiz barsak temizliği ( $\mathrm{p}=<0,001)$ inkomplet kolonoskopi lehine anlamlı saptandı. Uygun barsak hazırlığı yapılamayan ve işlem tekrarı önerilen $46(\% 6,1)$ vaka dışlandığında \%93,9'unda (667/710) kolonoskopi tamamlanmıştır. Kötü barsak hazırlığı inkomplet kolonoskopinin en sık nedeni olup $(\% 51,6)$, erkek cinsiyet (p=0,047) ve antiagregan-antikoagülan kullanımın ( $\mathrm{p}=0,021)$ kolon temizliğine etki eden faktörler olarak belirlenmiştir. Kolonoskopisi tamamlanan grupta polip saptanma oranı \%24,7 (165/ 667) olup güncel önerilen polip saptanma oranının altında kalmıştır.

Sonuç: Uygun olmayan barsak temizliği, ileri yaş, kadın cinsiyet, artan VKİ, komorbidite ve antiagregan/antikoagülan kullanımı inkomplet kolonoskopiye etki eden faktörlerdir. Uygun olmayan barsak temizliğinin ana nedeni olduğu yüksek inkomplet kolonoskopi oranı ve düşük polip saptama oranı nedeniyle kolonoskopi kalite standartlarının altında kaldığımız görülmektedir.

Anahtar Kelimeler: İnkomplet kolonoskopi, barsak hazırlığı, kolonoskopide kalite

\section{Introduction}

Colorectal cancers are common and the fourth most common malignancy-related cause of death worldwide. It is estimated that 2.2 million new diagnoses and 1.1 million mortality cases will develop annually by $2030 .{ }^{1}$ Colonoscopy; is a reliable method with high diagnostic accuracy and good patient tolerance under sedation which is frequently used in daily practice in the diagnosis and treatment of colorectal diseases. It is a gold standard in colorectal cancer screenings and significantly reduces the frequency and mortality of colorectal cancer by allowing adenomas to be removed. ${ }^{2,3}$ In colonoscopic evaluation; it is aimed to reach cecum safely and in some clinical situations it is aimed to evaluate the ileum. Cecum intubation is recommended in $90 \%$ of all colonoscopic procedures and 95\% of colonoscopies for screening purposes. One of the quality indicators of colonoscopic evaluation is cecum intubation and is not always possible. Incomplete colonoscopy rates are reported between $4-25 \% .{ }^{4,5}$ Adequate bowel preparation is the most important factor affecting completion rates. Inadequate bowel cleansing rate in all colonoscopy procedures is around 20-25\%. Inadequate bowel preparation reduces adenoma detection rates, prolongs the procedure time, increases workload and costs. ${ }^{5,6,7,8}$ Leading causes of incomplete colonoscopy include; inadequate colon cleansing, advanced age, female gender, low body mass index (BMI), previous abdominal or pelvic surgery, diverticulosis, long-tortious colon, procedure without sedation and inexperienced endoscopist. ${ }^{910,11,12,13,14}$ In our endoscopy unit, approximately 2000 colonoscopes are performed annually. It is important that clinics assess their own results, observe compliance with quality standards in the colonoscopy, and correct any deficiencies that are identified. In this study, it was aimed to evaluate incomplete colonoscopy rate, factors affecting incomplete colonoscopy and compliance of our clinic with colonoscopy quality standards.

\section{Materials and Methods}

Between January 1, 2017 and December 31, 2017, consecutive colonoscopic procedures were recorded prospectively in our endoscopy unit of our clinic. Adhering to the Helsinki declaration, the regional ethics committee for the study was approved. Participants were informed before the procedure and their written approval was received. In this study, individuals with American Society of Anesthesiologists (ASA) score of 1-2-3, without anesthetic agent allergy, outpatients, individuals older than 18 years of age and to whom procedure was applied under sedation were included. Individuals with ASA score of 4, patients who were urgently treated for bleeding and obstruction, patients with colorectal surgery history, presence of inflammatory bowel disease, those with malignancy compatible lesions during procedure, individuals who underwent therapeutic colonoscopy due to polyposis syndromes and known pathology were all excluded. Also, those who could not continue due to hypoxia, hypotension, allergic reaction, etc. during the procedure were excluded from the study.

Mechanical bowel preparation: three days before the colonoscopy appointment, soft food was given and clear food intake was provided one day before the procedure. Mechanical bowel clearance was achieved by the ingestion of $90 \mathrm{~mL}$ sodium phosphate (NaP) divided into two doses 8-12 hours before the procedure. Single dose of enema was given in the morning of procedure. An informative form, describing the diet and mechanical bowel cleansing, were given. A polyethyleneglycol (PEG) solution was given to the group (such as patients with kidney disease) where NaP uptake was not appropriate. Colon cleansing was divided into 4 categories according to Boston bowel preparation scale score. ${ }^{15,16}$ Score 0; unprepared colon segment with mucosa not seen because of solid stool that cannot be cleared, score 1 ; portion of mucosa of the colon segment seen, but other 
areas of the colon segment are not well seen because of staining, residual stool, and/or opaque liquid, score 2; minor amount of residual staining, small fragments of stool, and/ or opaque liquid, but mucosa of colon segment is seen well, score 3; entire mucosa of colon segment seen well, with no residual staining, small fragments of stool, or opaque liquid. Scores of 0 and 1 were considered as suboptimal, score of 2 and above were considered as optimal.

Colonoscopy procedure: all of the procedures were performed by a gastroenterologist/gastrointestinal surgeon with an experience of at least 500 colonoscopy procedures. All colonoscopic evaluations were performed with a video colonoscopy device (EC530WL3, Fujinon, Willich, Germany). Completion of colonoscopy; was defined as the visualization of ileocecal valve and appendiceal orifice or insertion into the ileum. The time elapsed from the anal entrance to the cecum was recorded in seconds and was defined as cecal intubation time. The evaluation of the colon mucosa and additional interventional procedures were performed while withdrawing from the cecum. Manoeuvre such as abdominal pressure, prone or supine position were recorded. Abdominal pressure and manoeuvre for changing position were separately grouped.

Anesthesia procedure: appropriate vein route was opened, 3-5 L/min oxygen is delivered with nasal cannula at left decubitus position, heart rate and saturation tracking was made with pulse oximeter. Blood pressure values were monitored at starting and every 5 minutes after that. Sedation was achieved mostly using the combination of midazolam, fentanyl and propofol under the control of a anesthesiologist. Age, gender, comorbid conditions, reason for colonoscopy, BMI, abdominopelvic surgery history, used antiagregantanticoagulant drugs, maneuvers during procedure, duration of cecal intubation, ratio and localization of detected polyps and diverticulitis were all determined. Polyp detection rates were considered to be valid for the complete colonoscopy group. Bowel preparation score and reason of incomplete procedure (pollution, risk of perforation due to presence of excessive diverticulum, looping, inadequacy of colonoscope length, sharp angulation etc.) were recorded. Populations, in whom colonoscopy was compeleted or not completed, were compared.

\section{Statistical Analysis}

Statistical software for statistical package for the social sciences (SPSS 22 Inc., Chicago, IL, USA) was used for biostatistical analysis (SPSS 22 Inc., Chicago, IL, USA). The data obtained from the patients participating in the study; were expressed as mean, standard deviation values and as percentage where necessary. The distribution of the data was checked by the Kolmogorov Smirnov test. Data with normal distribution were analyzed by student t-test. Group analysis of non-parametric data was made with Mann-Whitney U test. Categorical groups were compared with chi-square test. $\mathrm{P}<0.05$ was considered as statistically significant.

\section{Results}

Between the dates specified, 756 colonoscopies were performed in accordance with the study criteria. The mean age of the population was $54 \pm 12.7$ (range 18-88) years and $63 \%$ were female. The mean BMI was $28.3 \pm 4.8 \mathrm{~kg} / \mathrm{m}^{2}$, and there was comorbidity in 347 (45.9\%) patients. The general characteristics of the study population are summarized in Table 1. Colonoscopy was completed in 667 (88.2\%) subjects and the mean cecal intubation time was $355 \pm 187$ seconds. When 46 cases (6.1\%), who had incomplete bowel preparation and process should be repeated, were excluded; colonoscopy was completed in 93.9\% (667/710) of cases. The polyp detection rate was found to be $24.7 \%$ (165/667) and the frequency of diverticulum was $10.2 \%$. Bowel preparation was adequate in 588 cases (77.7\%) (Boston Bowel Preparation score $\geq 2$ ) whereas it was not optimal in 168 cases (22.2\%). The procedure was not completed in 89 people (11.8\%). When the causes of incomplete colonoscopy were examined; inadequate bowel preparation was in the first place with a ratio of $51.6 \%$ (Table 2). Looping (33.9\%) and intolerance (6.7\%) were the most common causes of incomplete colonoscopy in those with adequate colon cleansing. Other causes of incomplete colonoscopy include; sharp angulation in 4 cases (4.5\%), diverticulosis in 2 cases (2.2\%) and external compression in 1 case $(1.1 \%)$. The data obtained from the comparison of complete and incomplete colonoscopy groups were presented in Table 3. In comparison; age ( $\mathrm{p}=0.036)$, female gender $(\mathrm{p}=0.036)$, high BMI value $(\mathrm{p}=0.042)$, presence of comorbidity $(\mathrm{p}=0.004)$, use of antiagregant/anticoagulant $(\mathrm{p}=0.001)$, inadequate bowel cleansing $(\mathrm{p}<0.001)$ were found to be significant in favor of incomplete colonoscopy. Mean BMI value in incomplete and complete colonoscopy groups were $29.66 \pm 4.59$ and $27.30 \pm 4.83$, respectively and the difference between these two groups was significant ( $\mathrm{p}=0.042$ ). In the complete colonoscopy group, the rate of maneuvering was $56.1 \%$ while in the uncompleted group it was $38.2 \%$, which was statistically significant $(p<0.001)$. Previous abdominal and pelvic surgery had no effect on the completion of the colonoscopy procedure $(\mathrm{p}=0.172)$. When colon cleansing was separated into two groups in terms of being optimal and suboptimal; number of individuals with a bowel preparation score of 0 and 1 were (suboptimal) 168 (Table 4). When examining parameters affecting bowel cleansing; male gender and the use of antiagregant/ anticoagulant drug were found to be statistically significant. 
Table 1. Baseline characteristics of the population

\begin{tabular}{|c|c|c|}
\hline Variables & Total $(\mathrm{n}=756)$ & $\%$ \\
\hline Age $($ mean \pm SD) & $54 \pm 12.7$ & \\
\hline $\operatorname{Sex}(M / F)$ & $280 / 476$ & $37 / 63$ \\
\hline Comorbidity & 347 & 45.9 \\
\hline Hypertension & 224 & 29.6 \\
\hline Coroner artery disease & 120 & 15.9 \\
\hline Chronic obstructive pulmonary disease & 30 & 4 \\
\hline Chronic renal failure & 3 & 0.4 \\
\hline History of abdominal or pelvic surgery & 309 & 40.9 \\
\hline Gynecological & 176 & 23.3 \\
\hline Umbilical hernia & 16 & 2.1 \\
\hline Malignancy & 8 & 1.1 \\
\hline Antiagregan and/or anticoagulant use & 133 & 17.6 \\
\hline Aspirin & 76 & 10.4 \\
\hline Clopidegrol & 16 & 2.1 \\
\hline Coumadin & 25 & 3.3 \\
\hline Aspirin+clopidegrol & 13 & 1.7 \\
\hline Other & 3 & 0.1 \\
\hline \multicolumn{3}{|l|}{ Colonoscopy requirement } \\
\hline Constipation & 134 & 17.7 \\
\hline Follow-up after polypectomy & 51 & 6.7 \\
\hline Change in defecation habits & 24 & 3.2 \\
\hline Other reasons & 58 & 7.7 \\
\hline Complete colonoscopy & 667 & 88.2 \\
\hline Incomplete colonoscopy & 89 & 11.8 \\
\hline Cecal intubation time (second) $\pm \mathrm{SD}$ & $355 \pm 187$ & \\
\hline \multicolumn{3}{|l|}{ Bowel preparation score } \\
\hline 3 & 305 & 40.3 \\
\hline 2 & 283 & 37.4 \\
\hline 1 & 122 & 16.1 \\
\hline 0 & 46 & 6.1 \\
\hline Maneuvering rates & 327 & 43.3 \\
\hline Abdominal pressure & 168 & 22.2 \\
\hline Change of position & 33 & 4.4 \\
\hline Performing two maneuvers & 126 & 16.7 \\
\hline Polyp detection rate & $165 / 667$ & 24.7 \\
\hline Diverticule detection rate & 77 & 10.2 \\
\hline
\end{tabular}

BMI: Body mass index, F: Female, M: Male, SD: Standard deviation 
Table 2. Reasons for incomplete colonoscopy

\begin{tabular}{lcc} 
Reason for failure $(\mathbf{n}=89)$ & $\mathbf{n}$ & $\%$ \\
\hline Inadequate bowel preparation & 46 & 51.6 \\
\hline Looping and/or redundancy & 30 & 33.9 \\
Discomfort and intolerance & 6 & 6.7 \\
Angulation & 4 & 4.5 \\
Diverticulosis & 2 & 2.2 \\
External compression & 1 & 1.1
\end{tabular}

Table 3. Comparison of complete and incomplete colonoscopy populations

\begin{tabular}{|c|c|c|c|}
\hline Variables & $\begin{array}{l}\text { Complete } \\
\text { colonoscopy } \\
(\mathrm{n}, \%) \\
(\text { Total }=667)\end{array}$ & $\begin{array}{l}\text { Incomplete } \\
\text { colonoscopy } \\
(\mathrm{n}, \%) \\
(\text { Total=89) }\end{array}$ & $\mathrm{p}$ value \\
\hline Age $($ mean $\pm S D)$ & $53.03 \pm 12.7$ & $56.62 \pm 12.1$ & $0.036^{*}$ \\
\hline \multicolumn{4}{|l|}{ Sex } \\
\hline M & $250(37.5)$ & $30(33.7)$ & \multirow{2}{*}{$0.036^{*}$} \\
\hline $\mathrm{F}$ & $417(62.5)$ & $59(66.3)$ & \\
\hline $\mathrm{BMI}\left(\mathrm{kg} / \mathrm{m}^{2}\right) \pm \mathrm{SD}$ & $27.30 \pm 4.83$ & $29.66 \pm 4.59$ & $0.042 *$ \\
\hline \multicolumn{4}{|l|}{ Comorbidity } \\
\hline Yes & $294(44.1)$ & $53(59.6)$ & \multirow{2}{*}{$0.004 *$} \\
\hline No & $373(55.9)$ & $36(40.4)$ & \\
\hline $\begin{array}{l}\text { History of } \\
\text { abdominal or } \\
\text { pelvic surgery }\end{array}$ & $268(40.2)$ & $41(46.1)$ & 0.172 \\
\hline $\begin{array}{l}\text { Antiagregan and/ } \\
\text { or anticoagulant } \\
\text { use }\end{array}$ & $105(15.7)$ & $28(31.5)$ & $0.001 *$ \\
\hline \multicolumn{4}{|l|}{$\begin{array}{l}\text { Bowel preparation } \\
\text { score }\end{array}$} \\
\hline 3 & 373 (40.9) & $32(36)$ & \multirow{4}{*}{$<0.001^{*}$} \\
\hline 2 & $272(40.8)$ & $11(12.4)$ & \\
\hline 1 & $122(18.2)$ & $0(0)$ & \\
\hline 0 & $0(0)$ & $46(51.6)$ & \\
\hline \multicolumn{4}{|l|}{ Maneuvering rates } \\
\hline \multirow{4}{*}{$\begin{array}{l}\text { Abdominal } \\
\text { prossure } \\
\text { Change of position } \\
\text { Performing two } \\
\text { maneuvers }\end{array}$} & $374(56.1)$ & $34(38.2)$ & \multirow{4}{*}{$<0.001^{*}$} \\
\hline & $166(24.9)$ & $2(2.2)$ & \\
\hline & $33(4.9)$ & $0(0)$ & \\
\hline & $94(14.1)$ & $32(36)$ & \\
\hline
\end{tabular}

BMI: Body mass index, F: Female, M: Male, SD: Standard deviation, *: $\mathrm{p}<0.05$
Table 4. Comparison of factors affecting bowel preparation score

\begin{tabular}{llll} 
Variables & $\begin{array}{l}\text { Bowel } \\
\text { preparation } \\
\text { score } \geq 2 \\
(\text { Optimal n=587) }\end{array}$ & $\begin{array}{l}\text { Bowel } \\
\text { preparation } \\
\text { score 1 and 0 } \\
\text { Suboptimal } \\
\mathbf{n}=168)\end{array}$ & p value \\
\hline Age (mean \pm SD) & $53.88 \pm 12.8$ & $54.45 \pm 12.6$ & 0.603 \\
\hline $\begin{array}{l}\text { Sex } \\
\text { M }\end{array}$ & $208 / 280(74.3 \%)$ & $72 / 280(25.7 \%)$ & $0.047^{*}$ \\
F & $380 / 476(79.8 \%)$ & $96 / 476(20.1 \%)$ & 0.435 \\
$\begin{array}{l}\text { Comorbidity } \\
\text { History of } \\
\text { abdominal or } \\
\text { pelvic surgery }\end{array}$ & $261(44.4 \%)$ & $86(51.2 \%)$ & 0.477 \\
$\begin{array}{l}\text { Antiagregan and/ } \\
\text { or anticoagulant } \\
\text { use }\end{array}$ & $93(15.8 \%)$ & $40(23.8 \%)$ & $0.021^{*}$ \\
\begin{tabular}{l} 
BMI \pm SD \\
\hline
\end{tabular} & $28.2 \pm 4.7$ & $28.6 \pm 5.02$ & 0.357
\end{tabular}

BMI: Body mass index, F: Female, M: Male, SD: Standard deviation, *: $\mathrm{p}<0.05$

Ninety six $(57.1 \%)$ of the patients with suboptimal bowel cleansing were male $(\mathrm{p}=0.047)$. Colon cleansing was suboptimal in $25.7 \%$ (72/280) of male patients participating in the study, while colon cleansing was suboptimal in $20.2 \%(96 / 476)$ of female patients. The drug use ratio in adequate preparation group was $15.8 \%$ (93), whereas the drug use ratio in inadequate preparation group was $23.8 \%$ (40) $(\mathrm{p}=0.021)$. The polyp detection rate in completed colonoscopy group (165/667) was $24.7 \%$. Only 17 (17.9\%) polyps were detected in 122 patients with bowel cleansing score 1. Sigmoid colon (69), rectum (55) and descending colon (32) were the most common segments in which polyps were observed. Forty-five patients had polyps in more than one segment. Diverticulum was found in 77 (10.2\%) patients. Fifty-five of them (71.4\%) were seen in sigmoid colon, 24 were seen $(31.1 \%)$ in descending colon, 15 were seen in (19.4\%) transvers colon, 11 were seen in (14.3\%) ascending colon and 4 were seen in (5.4\%) cecum. In forty-four people $(57.1 \%)$ diverticulum was detected in more than one colonic segment.

\section{Discussion}

Colonoscopy is often used in diagnosis and treatment of colon diseases. It is safe, the rate of diagnosis is high and well tolerated when applied optimally. It is quite effective in preventing the development of colorectal cancer by allowing the detection and removal of premalign lesions. ${ }^{2,3,4,5}$ It is very important to evaluate the entire mucosa by reaching 
the proximal side of the ileocecal valve and removing all adenomas after detection. Cecum intubation is recommended in $90 \%$ of all colonoscopic procedures and $95 \%$ of colonoscopies for screening purposes. ${ }^{4}$ Undoubtedly it is very important that the bowel cleansing is adequate for a qualified evaluation. This shortens the time of cecal intubation and increases the rate of adenoma detection by allowing the entire mucosa to be examined. ${ }^{5,16,17}$ Incomplete colonoscopy causes are classified under three main headings. Patient related factors include; discomfort and intolerance, low BMI, tortuous-redundant colon, angule-fixed colon segment, prior abdominal-pelvic surgery, extensive diverticulosis, female sex, and young age. Technical factors include; severe looping, suboptimal preparation ve ineffective sedation. The third one is the experience of endoscopist. ${ }^{8,9,10,11,12,13,18,19,20}$ In a study of Koido et al., ${ }^{9}$ being older than 65 years of age, female gender, past abdominal or pelvic surgery, inadequate bowel cleansing, and inflammatory bowel disease were identified as factors affecting incomplete colonoscopy. When the factors affecting incomplete colonoscopy in our study were examined; advanced age, female gender, presence of comorbidity, high BMI, use of antiagregant and/or anticoagulant, and inadequate bowel preparation were found to be statistically significant. Although low BMI was defined as a factor that increases the duration of cecal intubation and decreases the rate of complete colonoscopy in the literature; different results were obtained in our study $(\mathrm{p}=0.042)$. However, the evaluation was not made after categorizing the BMI value; the result was weak and open to debate. Although the importance of bowel cleansing is known; in 2811 colonoscopy procedures, 925 (33\%) patients were reported to have inadequate colon cleansing in a prospective study by Hassan et al. ${ }^{18}$ Inadequate preparation leads to increased costs, increased workload in the health care system, missed precancerous lesions, and reduces the quality of colonoscopy. ${ }^{4,5,16,17,18}$ Advanced age, male sex, being inpatient, polypharmacy, constipation, cirrhosis, diabetes mellitus, Parkinson's disease, stroke, hypertension, previous colorectal surgery are conditions related with inadequate bowel preparation. ${ }^{16,17,18,21,22}$ In a prospective study of Hendry et al., ${ }^{23}$ including 10571 consecutive patients, inadequate bowel preparation was reported with a ratio of $16.9 \%$. In this study, inadequate bowel preparation and incomplete colonoscopy rates were found to be significantly higher, especially in the inpatient group. The incidence of incomplete colonoscopy was $11.8 \%$ in our study and in $46(6.1 \%)$ cases inadequate bowel preparation was found to be the most important cause. When patients with inadequate bowel preparation was excluded, colonoscopy was completed in $93.9 \%$ (667/710) of patients.
PEG is the most commonly used solution in bowel preparation worldwide. ${ }^{5,16,17}$ PEG solution in our country is not prescribed by physicians since it is not covered by health insurance. This may also lead to inadequate bowel preparation. Although different results were reported in the literature, there is no significant difference between $\mathrm{NaP}$ and PEG in terms of bowel cleansing. ${ }^{17}$ In 168 patients who were accepted as suboptimal with bowel preparation score of 1 and $0(22.2 \%)$, male gender $(\mathrm{p}=0.047)$ and antiagregantanticoagulant use $(\mathrm{p}=0.021)$ were determined as factors affecting bowel cleansing. It was seen that age, comorbid status, prior abdominal-pelvic surgery and BMI did not have any effect on bowel cleansing. Split-dose delivery of solutions for colon cleansing is strongly recommended. Besides after taking the second dose of solution; optimal colon cleansing rates can be achieved between $4-13^{\text {th }}$ hours. ${ }^{4,5,16,17}$ Practice in our clinic is using the second dose of $\mathrm{NaP}$ solution between 22-24 hours the night before the procedure. For about 9 hours passed during the day of procedure and this delay was longer for afternoon appointments. After this study, our clinical practice was revised. First dose of $\mathrm{NaP}$ was switched from 20:00 p.m. to 23:00 p.m. and the second dose was switched to one o'clock at night. In addition, prosedures are planned to be carried out predominantly between 08-12 hours. Other causes of incomplete colonoscopy include; looping in 30 cases (33.9\%), intolerance in 6 cases (6.7\%), sharp angulation in 4 cases (4.5\%), diverticulosis in 2 cases $(2.2 \%)$ and external compression in 1 case (1.1\%). Conscious and moderate sedation is often sufficient for colonoscopy. In young women, in those with chronic abdominal pain, longterm opiate users and those with abdominal surgical history; propofol-assisted sedation increases the success of procedure. ${ }^{8,24}$ In the presence of looping, sharp angulation, curved or long colon; abdominal compression under appropriate sedation, changing the position and using pediatric colonoscopy and endoscopy are most practical methods that can be used in endoscopy unit. If available, it would be appropriate to get help from the experienced endoscopist. ${ }^{8,11}$ Rex et al., ${ }^{25}$ completed colonoscopy in their study without a need of additional imaging method in $117 / 119$ patients who referred to them because of incomplete colonoscopy. In that study; procedures were completed with a high ratio under appropriate anesthesia, by adequate use of time and effective maneuvers and by using pediatric colonoscope or endoscope available in the endoscopy unit. ${ }^{25}$ However, standard colonoscopy may fail for several reasons in a small group of patients. In this case, current options include; magnetic endoscope imaging system Scope Guide (Olympus Optical), double-contrast barium enema, computed tomography or magnetic resonans colonography, overtube-assisted colonoscopy, double-balloon endoscopy, 
single-balloon endoscopy, colon capsule and C-Scan Cap imaging systems. ${ }^{8,19,26,27,28,29,30}$ In our country, auxiliary methods other than double-contrast barium enema are located in limited centers and their costs are high. The nontherapeutic approach and low diagnostic rates of barium scans are significant disadvantages. Therefore, the repeatability of the procedure by another endoscopist with sufficient experience should be the most logical first choice in our country for incomplete colonoscopy with appropriate bowel preparation and sufficient anesthesia support. One of the quality indicators of colonoscopy is adenoma detection rate. The American College of Gastroenterology and American Society for Gastrointestinal Endoscopy, suggest that adenoma detection rate should be at least $25 \% .{ }^{4}$ In the Polish study published in 2010, it was found that postcolonoscopy cancer development increased by more than 10 fold if adenoma detection rate was below 20\%. ${ }^{31}$ Improving adenoma detection rates on screening colonoscopies reduces interval colorectal cancer development and cancer-related mortality rates. ${ }^{32}$ The frequent occurrence of flat adenomas, aggressive tumor behavior, and late diagnosis in the proximal colon negatively affect prognosis. Therefore, careful evaluation of the proximal colon should be aimed at colonoscopies for screening and anemia., ${ }^{4,33}$ In a current study of van Renteln et al., ${ }^{34}$ long-term cecal intubation time was defined as a factor that can reduce adenoma detection rates. It is detected that when retrograd evaluation of cecum is conducted, at least 6 minutes should be given because adenoma detection rate can be decreased under this period. ${ }^{35}$ In our study, the detection rate of polyps in the complete colonoscopy group was $24.7 \%(165 / 667)$ and this was slightly below the currently recommended rate of adenoma detection. It will not be appropriate to comment on polyp detection rates because parameters such as endoscopist factor, retrograd evaluation from cecum and total procedure duration. Certainly there are some limitations of this study. Our sample size could be larger to make a strong recommendation. The endoscopist who performed the procedure was not specified. The most important reason for incomplete colonoscopy is the inadequacy of bowel cleansing but the factors for its causes are not elaborated. For example, no information is available regarding compliance with the dietary administration procedure and use of bowel preparation solution. The total duration of the procedure and how to approach to the incomplete colonoscopy group were not completed. The results of the revision in clinical practice in the intestinal preparation procedure have not yet been collected.

\section{Conclusion}

Incomplete colonoscopy ratio was $11.8 \%$ and adenoma detection ratio was detected as $24.7 \%$ which were below the guidelines recommendation. Inadequate bowel preparation, advanced age, female gender, presence of comorbidity, high BMI, antiagregant and/or anticoagulant use are factors affecting incomplete colonoscopy. Inadequate bowel preparation constitutes the majority of incomplete colonoscopy causes and continues to be a current problem. Male gender and use of antiagregant/anticoagulant are parameters that negatively affect inadequate bowel preparation. We anticipate that quality standards will be reached in colonoscopy by ensuring proper colon cleansing.

\section{Ethics}

Ethics Committee Approval: The study was approved by the University of Healty Sciences Kartal Koşuyolu Yüksek İhtisas Training and Research Hospital Local Ethics Committee (approval no: 2017.1/2-21).

Informed Consent: Consent form was filled out by all participants.

Peer-review: Externally peer-reviewed.

\section{Authorship Contributions}

Surgical and Medical Practices: U.A., E.G., R.K., S.A., Concept: U.A., E.G., E.P., E.B., Design: U.A., E.G., H.Ç., D.A.Ç., E.B., Data Collection or Processing: U.A., E.G., H.Ç., R.K., S.A., Analysis or Interpretation: U.A., E.B., E.P., S.A., Literature Search: U.A., H.Ç., D.A.Ç., R.K., E.P., Writing: U.A., E.G.

Conflict of Interest: No conflict of interest was declared by the authors.

Financial Disclosure: The authors declared that this study received no financial support.

\section{References}

1. Arnold M, Sierra MS, Laversanne M, Soerjomataram I, Jemal A, Bray F. Global patterns and trends in colorectal cancer incidence and mortality. Gut 2017;66:683-691.

2. Brenner H, Chang-Claude J, Jansen L, Knebel P, Stock C, Hoffmeister M. Reduced risk of colorectal cancer up to 10 years after screening, surveillance, or diagnosticcolonoscopy. Gastroenterology 2014;146:709-717.

3. Pan J, Xin L, Ma YF, Hu LH, Li ZS. Colonoscopy Reduces Colorectal Cancer Incidence and Mortality in Patients With Non-Malignant Findings: A Meta-Analysis. Am J Gastroenterol 2016;111:355-365.

4. Rex DK, Schoenfeld PS, Cohen J, Quality indicators for colonoscopy. Am J Gastroenterol 2015;110:72-90.

5. Johnson DA, Barkun AN, Cohen LB, Dominitz JA, Kaltenbach T, Martel M, Robertson DJ, Boland CR, Giardello FM, Lieberman DA, Levin TR, Rex DK, US Multi-Society Task Force on Colorectal Cancer. Optimizing adequacy of bowel cleansing for colonoscopy: recommendations from the US MultiSociety TaskForce on Colorectal Cancer. Gastroenterology 2014;147:903924.

6. Bowles CJ, Leicester R, Romaya C, Swarbrick E, Williams CB, Epstein O. Aprospective study of colonoscopy practice in the UK today: are we adequately preparedfor national colorectal cancer screening tomorrow? Gut 2004;53:277-283.

7. Marshall JB, Barthel JS. The frequency of total colonoscopy and terminal ilealintubation in the 1990s. Gastrointest Endosc 1993;39:518-520. 
8. Franco DL, Leighton JA, Gurudu SR. Approach to Incomplete Colonoscopy: New Techniques and Technologies. Gastroenterol Hepatol (NY). 2017;13:476-483.

9. Koido S, Ohkusa T, Nakae K, Yokoyama T, Shibuya T, Sakamoto N, Uchiyama K, Arakawa H, Osada T, Nagahara A, Watanabe S, Tajiri H. Factors associated with incomplete colonoscopy at a Japanese academic hospital. World J Gastroenterol 2014;20:6961-6967.

10. Liang CM, Chiu YC, Wu KL, Tam W, Tai WC, Hu ML, Chou YP, Chiu KW Chuah SK. Impact factors for difficult cecal intubation during colonoscopy. Surg Laparosc Endosc Percutan Tech 2012;22:443-446.

11. Brahmania M, Park J, Svarta S, Tong J, Kwok R, Enns R. Incomplete colonoscopy: maximizing completion rates of gastroenterologists. Can J Gastroenterol 2012;26:589-592.

12. Shah HA, Paszat LF, Saskin R, Stukel TA, Rabeneck L. Factors associated with incomplete colonoscopy: a population-based study. Gastroenterology 2007;132:2297-2303

13. Bernstein C, Thorn M, Monsees K, Spell R, O'Connor JB. A prospective study of factors that determine cecal intubation time at colonoscopy. Gastrointest Endosc 2005;61:72-75.

14. Jaruvongvanich $\mathrm{V}$, Sempokuya $\mathrm{T}$, Laoveeravat $\mathrm{P}$, Ungprasert P. Risk factors associated with longer cecal intubation time: a systematic review and metaanalysis. Int J Colorectal Dis 2018;33:359-365.

15. Lai EJ, Calderwood AH, DorosG, Fix OK, Jacobson BC. The Boston bowel preparation scale: a valid and reliable instrument for colonoscopy-oriented research. Gastrointest Endosc 2009;69:620-625.

16. Rutherfor CC, Calderwoo AH. Update on Bowel Preparation for Colonoscopy. Curr Treat Options Gastroenterol 2018;16:165-181

17. Parra-Blanco A, Ruiz A, Alvarez-Lobos M, Amorós A, Gana JC, Ibáñez $\mathrm{P}$, et al. Achieving the best bowel preparation for colonoscopy. World J Gastroenterol 2014;20:17709-17726.

18. Hassan C, Fuccio L, Bruno M, Pagano N, Spada C, Carrara S, Giordanino C, Rondonotti E, Curcio G, Dulbecco P, Fabbri C, Della Casa D, Maiero S, Simone A, Iacopini F, Feliciangeli G, Manes G, Rinaldi A, Zullo A, Rogai F, Repici A. A predictive model identifies patients most likely to have inadequate bowel preparation for colonoscopy.Clin Gastroenterol Hepatol 2012;10:501-506

19. Villa NA, Pannala R, Pasha SF, Leighton JA. Alternatives to Incomplete Colonoscopy. Curr Gastroenterol Rep 2015;17:43.

20. Hanson ME, Pickhardt PJ, Kim DH, Pfau PR. Anatomic factors predictive of incomplete colonoscopy based on findings at CT colonography. AJR Am J Roentgenol 2007;189:774-779

21. ASGE Standards of Practice Committee, Saltzman JR, Cash BD, Pasha SF, Early DS, Muthusamy VR, Khashab MA, Chathadi KV, Fanelli RD, Chandrasekhara V, Lightdale JR, Fonkalsrud L, Shergill AK, Hwang JH, Decker GA, Jue TL, Sharaf R, Fisher DA, Evans JA, Foley K, Shaukat A, Eloubeidi MA, Faulx AL, Wang A, Acosta RD.Bowel preparation before colonoscopy. Gastrointest Endosc 2015;81:781-794.

22. Jawa H, Mosli M, Alsamadani W, Saeed S, Alodaini R, Aljahdli E, Bazarah S, Qari Y. Predictors of inadequate bowel preparation for inpatient colonoscopy. Turk J Gastroenterol 2017;28:460-464.
23. Hendry PO, Jenkins JT, Diament RH. The impact of poor bowel preparation on colonoscopy: a prospective single centre study of 10,571 colonoscopies Colorectal Dis 2007;9:745-748.

24. Standards of Practice Committee, Lichtenstein DR, Jagannath S, Baron TH, Anderson MA, Banerjee S, Dominitz JA, Fanelli RD, Gan SI, Harrison ME, Ikenberry SO, Shen B, Stewart L, Khan K, Vargo JJ. Sedation and anesthesia in GI endoscopy. Gastrointest Endosc 2008;68:205-216.

25. Rex DK, Chen SC, Overhiser AJ. Colonoscopy technique in consecutive patients referred for prior incomplete colonoscopy. Clin Gastroenterol Hepatol 2007;5:879-883.

26. Spada C, Hassan C, Barbaro B, Iafrate F, Cesaro P, Petruzziello L, Minelli Grazioli L, Senore C, Brizi G, Costamagna I, Alvaro G, Iannitti M, Salsano M, Ciolina M, Laghi A, Bonomo L, Costamagna G. Colon capsule versus CT colonography in patients with incomplete colonoscopy: a prospective, comparative trial. Gut 2015;64:272-281.

27. Chen Y, Duan YT, Xie Q, Qin XP, Chen B, Xia L, Zhou Y, Li NN, Wu XT Magnetic endoscopic imaging vs standard colonoscopy: meta-analysis of randomized controlled trials. World J Gastroenterol 2013;19:7197-7204.

28. Hotta K, Katsuki S, Ohata K, Abe T, Endo M, Shimatani M, Nagaya T, Kusaka T, Matsuda T, Uraoka T, Yamaguchi Y, Murakami Y, Saito Y. A multicenter, prospective trial of total colonoscopy using a short doubleballoon endoscope in patients with previous incomplete colonoscopy. Gastrointest Endosc 2012;75:813-818.

29. Yamada A, Watabe H, Takano N, Togo G, Yamaji Y, Yoshida H, Kawabe T, Omata M, Koike K. Utility of single and double balloon endoscopy in patients with difficult colonoscopy: a randomized controlled trial. World J Gastroenterol 2013;19:4732-4736.

30. Spada C, Pasha SF, Gross SA, Leighton JA, Schnoll-Sussman F, Correale L, González Suárez B, Costamagna G, Hassan C. Accuracy of first- and second-generation colon capsules in endoscopic detection of colorectal polyps: a systematic review and meta-analysis. Clin Gastroenterol Hepatol 2016;14:1533-1543.

31. Kaminski MF, Regula J, Kraszewska E, Polkowski M, Wojciechowska U, Didkowska J, Zwierko M, Rupinski M, Nowacki MP, Butruk E. Quality indicators for colonoscopyand the risk of interval cancer. N Engl J Med 2010;362:1795-1803

32. Kaminski MF, Wieszczy P, Rupinski M, Wojciechowska U, Didkowska J, Kraszewska E, Kobiela J, Franczyk R, Rupinska M, Kocot B, ChaberCiopinska A, Pachlewski J, Polkowski M, Regula J. Increased rate of adenoma detection associates with reduced risk of colorectal cancer and death. Gastroenterology 2017;153:98-105.

33. Aday U, Gundes E, Ciyiltepe H, Cetin DA, Deger KC, Gulmez S, Senger AS, Bozdag E. Does antiaggregant administration lead to early diagnosis in proximal colon cancer? North Clin Istanb 2017;4:173-179.

34. von Renteln D, Robertson DJ, Bensen S, Pohl H. Prolonged cecal insertion time is associated with decreased adenoma detection. Gastrointest Endosc 2017:85:574-580

35. Barclay RL, Vicari JJ, Doughty AS, Johanson JF, Greenlaw RL. Colonoscopic withdrawal times and adenoma detection during screening colonoscopy. N Engl J Med 2006;355:2533-2541 